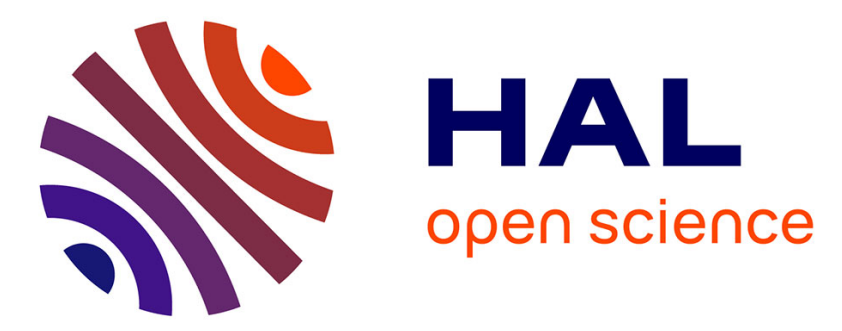

\title{
Hares on thin ice: Introgression of mitochondrial DNA in hares and its implications for recent phylogenetic analyses
}

Paulo C. Alves, D. James Harris, José Melo-Ferreira, Madalena Branco, Nuno Ferrand, Franz Suchentrunk, Pierre Boursot

\section{To cite this version:}

Paulo C. Alves, D. James Harris, José Melo-Ferreira, Madalena Branco, Nuno Ferrand, et al.. Hares on thin ice: Introgression of mitochondrial DNA in hares and its implications for recent phylogenetic analyses. Molecular Phylogenetics and Evolution, 2006, 40 (2), pp.640-641. 10.1016/j.ympev.2006.02.016 . halsde-00300398

\section{HAL Id: halsde-00300398 https://hal.science/halsde-00300398}

Submitted on 19 Jan 2021

HAL is a multi-disciplinary open access archive for the deposit and dissemination of scientific research documents, whether they are published or not. The documents may come from teaching and research institutions in France or abroad, or from public or private research centers.
L'archive ouverte pluridisciplinaire HAL, est destinée au dépôt et à la diffusion de documents scientifiques de niveau recherche, publiés ou non, émanant des établissements d'enseignement et de recherche français ou étrangers, des laboratoires publics ou privés. 
Hares on thin ice: Introgression of mitochondrial DNA in hares and its implications for recent phylogenetic analyses

Paulo C. Alves ${ }^{1,2}$, D. James Harris ${ }^{1,2}$, ${ }_{\text {, José Melo-Ferreira }}^{1,2,4}$, Madalena Branco ${ }^{1,2}$, Nuno Ferrand $^{1,2}$, Franz Suchentrunk ${ }^{3}$ and Pierre Boursot ${ }^{4}$.

1. CIBIO/UP, Centro de Investigação em Biodiversidade e Recursos Genéticos, Universidade do Porto, Campus Agrário de Vairão, 4485-661 Vairão, Portugal

2. Departamento de Zoologia e Antropologia, Faculdade de Ciências da Universidade do Porto, Portugal

3. Research Institute of Wildlife Ecology, University of Veterinary Medicine, Vienna, Austria 4. UMR 5171, Génome Population Interaction Adaptation, Université Montpellier II, France

*Corresponding author: james@mail.icav.up.pt

Mitochondrial DNA has long been used to infer phylogenetic relationships among taxa and help revising the taxonomy. When dealing with recently diverged and potentially hybridizing taxa however, one must bear in mind that mtDNA is essentially a single locus, with a peculiar mode of transmission. Confounding population history with that of mtDNA alone can be misleading because of erroneous amplification of mitochondrial pseudogenes inserted in the nuclear genome (numts; Thalmann et al., 2005), due to the stochastic nature of lineage sorting during speciation, or even more seriously because of possible secondary introgressions (see, e.g., Ballard and Whitlock, 2004 or Nichols, 2001).

Hybridization and mtDNA introgression are phenomena that can leave traces of ancient history on the mitochondria, shaping and introducing errors on naive phylogenies. Hybridization and cytoplasmic genome introgression are frequent in plants (see Arnold, 1997), but reports of such cases 
in animals are accumulating in the literature (see Avise, 2004 for a compilation), including cases of contemporaneous or past introgression, sometimes even resulting in a complete interspecific mitochondrial replacement (Bernatchez et al., 1995). Examples in mammals include pocket gophers (Ruedi et al., 1997), deer (Goodman et al., 1999) and elephants (Roca et al., 2005). It is now clear that genomes remain porous long after speciation is completed, allowing multiple opportunities for widespread introgression and, thus, misinterpretations of single gene genealogies (Chan and Levin, 2005; Mallet, 2005).

Although introgression of mtDNA from the mountain hare, Lepus timidus, into populations of the brown hare

L. europaeus has been described for almost a decade (Thulin et al., 1997), phylogenies of various hare species groups have been estimated based solely on mtDNA (e.g., Pierpaoli et al., 1999; Wu et al., 2000) and even used to support or refute taxonomic units (Halanych et al., 1999), ignoring the possible problem of introgression when using a single marker. However, in the mtDNA phylogeny of 15 hare species presented in Alves et al. (2003), a lineage that appeared specific of $L$. timidus also contained representatives of several other species, and these authors warned that this could be an indication of introgression of L. timidus mtDNA into as many as eight species ( $L$. granatensis, L. europaeus, L. arcticus, L. castroviejoi, L. corsicanus, L. oiostolus, L. othus and L. townsendii). By comparison with the phylogeny of the nuclear gene transferrin of some of these species, they confirmed that some Iberian specimens of L. granatensis and L. europaeus harbored mtDNA of L. timidus origin, which was unexpected since L. timidus has disappeared from the Iberian Peninsula during the last deglaciation (Altuna, 1970). Further analysis of 695 hares from the Iberian Peninsula clearly demonstrated that the introgressed L. timidus mtDNA is widespread in the northern regions, being predominant in L. granatensis populations, almost fixed in L. europaeus across its Iberian range, and present in L. castroviejoi as well (Melo-Ferreira et al., 2005).

Somewhat surprisingly, three recent articles have addressed arctic hare relationships based solely on mtDNA sequences, without discussing the possible impact of introgression (Waltari et al., 2004; Waltari and Cook, 2005; Wu et al., 2005). These articles make important taxonomic and biogeographic proposals based on this data. Wu et al. (2005) used mtDNA data to infer phylogenetic relationships among nine presently recognized hare species from China and include GenBank sequences to extend the analysis to 24 worldwide species. The same data set was further used to infer the evolutionary biogeography of the genus Lepus and to date the putative speciation events. These authors suggest two southern European species, L. corsicanus and L. castroviejoi, to 
be considered subspecies of L. timidus, neglecting the fact that these species are suggested to have introgressed mtDNA (Alves et al., 2003), have distinct morphologies and that their nuclear gene pool re- mains unexamined. Further, L. coreanus, L. arcticus and L. othus are considered L. timidus by Wu et al. (2005) without further evidence from nuclear markers. Since L. capensis from China also has L. timidus mtDNA, Wu et al. (2005) assume " the Cape Hare does not exist in China'. Using the same argument, we would have concluded that L. granatensis and L. europaeus do not exist in some locations in the Iberian Peninsula. Waltari et al. (2004) and Waltari and Cook (2005) infer the arctic hares phylogeny as well as historical population decreases in L. othus and L. arcticus, based exclusively on the mitochondrial control region. MtDNA monophyly of L. arcticus and L. othus is believed to support species classification although L. timidus is clearly paraphyletic. Again, introgression from L. timidus is a possibility that cannot be overlooked and, without additional nuclear evidence, the history of these other arctic hares cannot be completely understood.

To conclude, as has repeatedly been stated before, "one is not enough" (Ballard, 2000), and the evolutionary history of the genus Lepus is a remarkable example of this. Introgression of L. timidus mtDNA into other hare species appears widespread, fixed in some populations andperhaps even in some species, possibly indicating a selective advantage to the introgressed lineage, as suggested by Melo-Ferreira et al. (2005). Since this introgression must be ancient, at least in some cases such as in the Iberian Peninsula, it is unsurprising that these populations now contain unique haplotypes relative to bona fide L. timidus specimens.

Hares promise to be an exciting model to study mtDNA evolution, hybridization and adaptation, provided the right questions are asked and the right tools used to address them. But hare phylogeny and taxonomy based solely on mtDNA and ignoring potential introgression is treading on thin ice indeed.

\section{Acknowledgments}

We thank the anonymous reviewers for their constructive criticisms on an early version of this letter. This work was partially supported by Fundação para a Ciência e a Tecnologia (projects POCTI/BSE/41457/2001, POCI 2010/BIA- BDE/58817/2004, and SFRH/BD/13160/2003 PhD Grant to J.M.F.). 


\section{References}

Altuna, J., 1970. Hallazgo de una liebre ártica (Lepus timidus) en el yacimiento prehistó rico de Urtiga (Guipú zcoa). Munibe San Sebastean 22, 165-168.

Alves, P.C., Ferrand, N., Suchentrunk, F., Harris, D.J., 2003. Introgression in Iberian hares (Lepus spp) inferred from mitochondrial and nuclear DNA sequences. Mol. Phylogenet. Evol. 27, 70-80.

Arnold, M., 1997. Natural Hybridization and Evolution. Oxford University Press, Oxford.

Avise, J.C., 2004. Molecular Markers, Natural History and Evolution, second ed. Sinauer Associates, Massachusetts.

Ballard, J.W.O., 2000. When one is not enough: introgression of mitochondrial DNA in Drosophila. Mol. Biol. Evol. 17, 1126-1130.

Ballard, J.W.O., Whitlock, M.C., 2004. The incomplete natural history of mitochondria. Mol. Ecol. 13, 729-744.

Bernatchez, L., Glé met, H., Wilson, C., Danzmann, R., 1995. Introgression and fixation of Arctic char (Salvelinus alpinus) mitochondrial genome in an allopatric population of brook trout (Salvelinus fontinalis). Can. J. Fish. Aqu. Sci. 52, 179-185.

Chan, K.M.A., Levin, S.A., 2005. Leaky prezygotic isolation and porous genomes: rapid introgression of maternally inherited DNA. Evolution 59, 720-729.

Goodman, S., Barton, N., Swanson, G., Abernethy, K., Pemberton, J., 1999. Introgression through rare hybridisation: a genetic study of a hybrid zone between Red and Sika Deer (genus Cervus) in Argyll, Scotland. Genetics 152, 355-371.

Halanych, K.M., Demboski, J.R., van Vuuren, B.J., Klein, D.R., Cook, J.A., 1999. Cytochrome $b$ phylogeny of North American hares and jackrabbits (Lepus, Lagomorpha) and the effects of saturation in outgroups taxa. Mol. Phylogenet. Evol. $11,213-221$.

Mallet, J., 2005. Hybridization as an invasion of the genome. TREE 20, 229-237.

Melo-Ferreira, J., Boursot, P., Suchentrunk, F., Ferrand, N., Alves, P.C., 2005. Invasion from the cold past: extensive introgression of mountain hare (Lepus timidus) mitochondrial DNA into three other hare species in northern Iberia. Mol. Ecol. 14, 2459-2464.

Nichols, R., 2001. Ancient introgression of Lepus timidus mtDNA into L. granatensis and $L$. europaeus in the Iberian Peninsula. TREE 16, 358-364.

Pierpaoli, M., Riga, F., Trocchi, V., Randi, E., 1999. Species distinction and evolutionary 
relationships of the Italian hare (Lepus corsicanus) as described by mitochondrial DNA sequencing. Mol. Ecol. 8, 1805-1817.

Roca, A., Georgiadis, N., O’Brien, S.J., 2005. Cytonuclear genomic dissociation in African elephant species. Nature Genet. 37, 96-100.

Ruedi, M., Smith, M.F., Patton, J.L., 1997. Phylogenetic evidence of mitochondrial DNA introgression among pocket gophers in New Mexico (family Geomyidae). Mol. Ecol. 6, 453-462.

Thalmann, O., Serre, D., Hofreiter, M., Lukas, D., Eriksson, J., Vigilant, L., 2005. Nuclear insertions help and hinder inference of the evolutionary history of gorilla mtDNA. Mol. Ecol. 14, 179-188.

Thulin, C.-G., Jaarola, M., Tegelströ m, H., 1997. The occurrence of mountain hare mitochondrial DNA in wild brown hares. Mol. Ecol. 6, 463-467.

Waltari, E., Demboski, J.R., Klein, D.R., Cook, J.A., 2004. A molecular perspective on the historical biogeography of the northern high latitudes. J. Mammal. 85, 591-600.

Waltari, E., Cook, J.A., 2005. Hares on ice: phylogeography and historical demographics of Lepus articus, L. othus and L. timidus (Mammalia: Lagomorpha). Mol. Ecol. 14, 30053016.

Wu, C., Li, H., Wang, Y., Zhang, Y., 2000. Low genetic variation of the Yunnan hare (Lepus comus G. Allen 1927) as revealed by mitochondrial Cytochrome $b$ gene sequences. Biochem. Genet. 38, 147-153.

Wu, C., Wu, J., Bunch, T.D., Li, Q., Wang, Y., Zhang, Y., 2005. Molecular phylogenetics and biogeography of Lepus in Eastern Asia based on mitochondrial DNA sequences. Mol. Phylogenet. Evol. 37, 45-61. 